\title{
Self-determination and life satisfaction: An exploratory study with veteran judo athletes
}

\author{
Marco BATISTA ${ }^{* 1,3}$, Ruth Jimenez CASTUERA ${ }^{2}$; Samuel HONÓRI01,3, João PETRICA ${ }^{1,4}$, \& João \\ SERRANO ${ }^{1,4}$ \\ ${ }^{1}$ Superior School of Education - Polytechnic Institute of Castelo Branco (Portugal) \\ ${ }^{2}$ Extremadura University - Sports School (Spain) \\ ${ }^{3}$ RECI - Research, Education and Community Intervention (Portugal) \\ ${ }^{4}$ FCT and CI\&DETS (Pest-OE/CED/UI4016/2011) (Portugal)
}

\section{5th IMACSSS World Scientific Congress Abstracts, Rio Maior (Portugal), October 6-8 Section: Psychological, pedagogic and didactics in MA\&CS Type: Poster communication}

\section{Introduction}

The Theory of Self-determination (Deci \& Ryan, 2002) is based on a motivational domain and leads to the importance of meeting basic psychological needs of perception of autonomy, perception of competence and perception of social relations in the appearance of self-determined behaviour, which are those that cause series of consequences as the future commitment to sports or exercise (Palmeira, 2010) and what kind of affection promotes to them a perspective of a life satisfaction (Andrews \& Withey, 1976). According to studies relating the degree of self-determination based on different training habits and athletic history, veterans athletes revealed high levels of intrinsic motivation, moderate extrinsic motivation and almost inexistence in terms of amotivation once that for these athletes the most important aspect of this sport is the satisfaction by overcoming their own limits during training and then to overcome opponents in competitions, hoping for a medal, or even a record (Sancho \& Ruiz-Juan, 2015). This exploratory study aims, in the context of veteran sport, i) characterise the motivation and satisfaction of basic psychological needs to practice judo; ii) to know the level of satisfaction with life; and iii) to understand which variables of selfdetermination influence levels of affection and satisfaction with life.

\section{Methodology}

The sample of this study is based on 104 veteran judo athletes, 80 males (M) and 24 females (F) (ages: $43.7 \pm 9.7$ years; week training time: $2.4 \pm 0.7 \mathrm{~h}$; Years of Practice: $20.3 \pm 10.9$ ). All individuals filled the Portuguese versions questionnaires of Basic Psychological Needs Exercise Scale (BPNES) from Moutão, Cid, Alves, Leitão and Vlachopoulos (2012) in a five-level Likert scale, Behavioral Regulation in Sport Questionnaire (BRSQ) validated by Monteiro, Moutão, Baptista and Cid (2014) in a seven-level scale, Satisfaction With Life Scale (Neto, 1993) in a seven-level scale, Positive and Negative Affection Scale - PANAS (Galinha \& Pais-Ribeiro, 2005) of a five-level scale, in which participants recorded their demographic data. Answers were quantified in SPSS (IBM, Statistics 21.0) for statistical processing. Descriptive statistics was used and also we have applied an analysis of Pearson Correlation Coefficient and multiple linear regression. The level of significance was settled at $\mathrm{p}<0.05$.

\section{Results}

The sample showed high levels in basic psychological needs, perception of autonomy (4.2), perception of competence (4.2) and perception of social relations (4.5). They also showed a high 
autonomous motivation (6.1) as well as lower values in terms of controlled motivation (1.9) and amotivation (2.2). In our well-being indicators, the level of life satisfaction (5.3), positive emotions (3.7) and negative affect (1.7).

Referring to the correlation test, the basic psychological needs showed positive and significant correlations with autonomous motivation levels, life satisfaction and positive affect. Life satisfaction levels showed significant positive correlations with autonomous motivation levels and positive affects, and negative and significant correlations with controlled motivation, amotivation and negative affects.

In terms of linear regression analysis, with the variable life satisfaction as a dependent one, in order to test which variables positively predicted that same variable, we have confirmed that the collinearity statistics (Tolerance and IVF) have shown that they were not collinear. Hence, life satisfaction is positively and significantly predicted by the variable positive affects and negatively and significantly by negative affects. The variables of self-determination explain $20 \%$ of the variance, which when associated with affections produced in the competition explain $38 \%$ of the variance.

\section{Discussion and conclusion}

Veteran's judo athletes have shown a high autonomous motivation, as well as a high satisfaction of basic psychological needs. These results are related to the appearance of self-determined behaviour (Deci \& Ryan, 2002), promoting, according to Palmeira (2010), higher levels of commitment to sport.

The levels of satisfaction with life obtained were in fact quite expressive. However, they can be improved. As referred by Andrews and Withey (1976) levels of satisfaction with life are highly dependent on the affections produced in practice, which could be improved as well. The predictive basis by the variables of self-determination is also something to be considered, which leads to the tendency indicated by Sancho and Ruiz-Juan (2015), where the veteran athletes show high levels of intrinsic motivation and satisfaction by overcoming during training.

In conclusion, the practice of Judo promotes in veteran athletes a better self-determined behaviour and a good satisfaction with life.

\section{References}

Andrews, F. M., \& Withey, S. B. (1976). Social indicators of well-being: The development and measurement of perceptual indicators. New York: Plenum.

Deci, E. L., \& Ryan, R. M. (2002). Self-determination research: Reflections and future directions. In E. L. Deci \& R. M. Ryan (Eds), Handbook of self-determination research (pp. 431-44). Rochester, NY: University of Rochester Press.

Galinha, I. \& Pais Ribeiro, J. (2005). Contribuição para o estudo da versão portuguesa da Positive and Negative Affect Schedule (PANAS): II - Estudo psicométrico. Análise Psicológica, 2(23), 219227

Monteiro, D., Moutão, J., Baptista, P., \& Cid, L. (2014). Motivational climate, behaviour regulation and perceived effort in soccer athletes. Motricidade, 10(4) 94-104.

Moutão, J., Cid, L., Alves, J., Leitão, J., \& Vlachopoulos, S. (2012). Validation of the Basic Psychological Needs in Exercise Scale in a Portuguese Sample. The Spanish Journal of Psychology, 15(1), 399409.

Neto, F. (1993). The Satisfaction with Life Scale: Psychometrics Properties in an Adolescent Sample. Journal of Youth and Adolescence, 22(2), 125-134.

Palmeira, A. L. (2010). Análise do poder preditivo da teoria do comportamento planeado na adesão ao exercício. Revista Gymnasium, 1(3), 98-120.

Sancho, A. Z., \& Ruiz-Juan, F. (2015). Factores determinantes de la motivación en atletas veteranos españoles. Revista Latinoamericana de Psicología, 47(1), 34-42.

Key words: Self-determination; Judo; combat sports; well-being. 